sick-list book than I had legitimately attended. To this base insinuation I replied, through the Poor-law Board, that, having held very responsible positions in India, under the Government, with valuable testimonials of ability and rectitude of conduct, I did not stand in need of the board of guardians pointing out to me what was a line of condnct in accordance with integrity and honour; and that, as the cases referred to were remitted, individually named in the sick-list, fortnightly, for their inspection, the argument for their repudiation was untenable, as no objection had been raised at either instance of their inspections. Their next plea for refusal was, that most of the cases recorded had been attended by me without especial authority. In our union, it is not usual to send to the relieving officer for orders in all the cases of applicants for union medical relief. Each medical officer knows his district well, and all the respective poor in them entitled to pauper medical relief; and as the districts are very extensive, the relieving-officer requires to be away from his house, on his own duties, almost daily, from morning till night; that to refuse to attend most of the applicants until they had obtained the order of the official would be seriously inconvenient, and a gross injustice and uncharitable to the poor, many of whom have to travel miles, or to relinquish their employment, when waiting on their medical attendant.

I regret to inform my medical brethren that, after a considerably lengthened correspondence with the board of guardians, the Poor-law Board terminated the matter by wigging me for irregularity, and recommended me, for the future, to be more strict in complying with the rules, of which $I$ have just shown the injustice.

I was not in a position to resign my appointment as district medical officer, and I deeply regretted it. Would that there were sufficient unanimity in our profession, that we could chastise our aggressors, when they venture unwarrantably to trample upon us! As if impressed with the necessity and propriety of having rank and education in the board, conscience stricken, the board of guardians have now elected and obtained a gentleman, possessing both, to the office of chairman. Need I say I failed in obtaining the remuneration I songht for, and there the matter rests?

Surely the Government and the public would never wish such irresponsible powers to be wielded by boards of guardians as it is shown so frequently they do wield; and may wo hope the day is not far distant, when poor-law union surgeons may look to the Government for approval or for censure, and their corresponding rewards and punishments.

There are two taxes, which I think, on due representation, might be remitted to our much-oppressed class- that of turnpike tolls, and of one horse and carriage, used for the benetit of the poor, and especially in the duties attached to the office of poor. law mion surgeon. Officers of the army on duty always pass through tools free of expense, and to many of the country general practitioners, doing pauper union duty, a similar concession would be very valuable. To visit some of my pauper patients in a carriage, by the direct road, would cost me $10 \frac{1}{2} d$. Remission of tax on one horse and carriage, and perhaps it may be conceded, on one man-servant-a necessary requisitewould to some extent tend to relieve the already much-imposedupon union medical officer.

I beg to remain, Sir,

Your obedient servant

Aynoti J. J. Chitry, M.R.C.S.E., \&c.,

Mere, Wilts, June, 1854. Medical Oficer, 2nd District, Mere Union.

\section{THE ASSOCIATION JOURNAL AND}

DR. CORMACK.

To the Editor of THE LAxceT.

SIR,--I have often felt surprised that you have not called the Editor of the Association Journal to account for the grossly vulgar and slanderous language in which he indulges in the leading articles of the periodical entrusted to bis care-language which, before his advent, was certainly foreign to the medical press, and which I believe to be utterly distasteful to the great bulk of the members of the Association to which the Journal belongs. It is really astonishing how any man, under the guise of Calvinistic puritanism, with pretensions to the most sanctimonious rigiality, and an affectation of evangelical meekness, can gather together such a mass of ribald language as he frequently includes in what must, I suppose by courtesy, be called leading articles. If our lugubrious Editor quotes prose, it is pretty sure to be from Holy Writ; if poetry, it is almost as certainly from Watts' Hymns or Young' Night Thoughts; but with the highest reverence for such matters, I venture to demur to their being profanely introduced to bolster up bad arguments or meagre ideas.

I read the Association Journal and THE LANCET habitually, and I felt indignant when I saw in the Journal of May 12th an odious slander against the whole profession. It refers to THE LANCET, it is true; but it is substantially a vilification of the medical men of this country as a body. The libel I refer to is as follows:-

"When THE LANCET imputes vile and Gishonourable conduct to individuals, it is chiefly because his readers must have spicy and abusive articles. THE LANCET commands an adequate sale by trafficking in calumnies, and until the morality and good taste of the profession become improved, it would be a commercial blunder in our contemporary to write in a different style from that which he now adopts."

Now, Sir, this is not an attack upon you, but upon the profession itself. With respect to the style of the writing in the leading articles of THE LANCET, I will only say that I believe there is not a man in the profession who has not often read them with pride and pleasure. For power of language, fertility of thought, and felicity of expression, they may, in my opinion, challenge comparison with any of the periodical writing of the day.

Of the style of the Association Journal, the passage I have quoted is not so bad a specimen as might easily have been selected. But with respect to the odious aspersion against medical men, that bad language, "abusive articles," "trafficking in calumnies," and the imputation of "vile and dishonourable conduct," are required by the "taste of the pro. fession," I hurl it back upon Dr. Cormack, as a most base and wicked calumny, a calumny especially hateful, as coming from a medical journalist, and the more reprehensible as it is accom. panied by ostentatious pretensions to extraordinary virtue and purity. I am, Sir,

Ax OLd SUbscriber of THe Lancet, ANd A Member of The Provinclal Assoctation.

\section{DISCREPANCIES IN ANALYSIS.}

\section{To the Editor of The LaNoet.}

SIR,-I beg to submit the following, should you deem it worthy of insertion in THE LANCET. At the same time that it points out a very great discrepancy in the analysis alluded to, I think the processes adopted by me will be found to give more satisfactory results than those at present in use.

The circumstances are these :-A short time since a friend of mine consulted a medical gentleman for diabetes mellitus, who made an analysis of his urine; and from the large quantity of urea stated to exist, I suspected an error had been made, since it is generaliy admitted that urea decreases in proportion as the sugar increases, and in some instances does not obtain at all. The specific gravity of the urine was 1.035. Dr. Bstates that every fluid ounce contained 30.02 of sugar, and $10 \cdot 25$ urea. Now, 1000 grains of urine are equal in measure to $2 \frac{1}{4}$ ounces; so that

$$
\begin{aligned}
& \text { if } 1 \text { fluid ounce contains ... } \quad \ldots \quad 30 \mathrm{gr} \text {. and } 10 \frac{1}{\mathrm{gr}} \text {. } \\
& 2 \frac{1}{4}\left(\text { or } 1000 \text { gxs.) contain } \ldots 6^{\prime} \quad \ldots 7 \frac{1}{2} \text { and } 23 \frac{1}{4}=90 \frac{3}{4}\right.
\end{aligned}
$$

$90 \frac{3}{4}$ grains would therefore be the estimate of urea and sugar per 1000 , without taking into account the saline matter.

I examined the same patient's urine, and found the specific gravity to be, by balance, 1.033. 1000 grains weree vaporated to $\frac{1}{6}$ th, and an equal bulk of strong nitric acid added, and the resulting crystals of nitrate of urea, on being pressed and dried, gave 12 grains, and since the combining proportions of nitric acid and anhydrous urea are about equal, 6 grains would be the whole amount of urea obtained. The various pieces of paper on which the crystals were pressed and dried, on being digested in distilled water, and the draining of the crystals added and evaporated to absolute dryness, gave, as

solid matter ...

to which, if we add the 6 grains of urea previonsly extracted ... 70 grs.

we get, as the actual dry contents per 1000,76 grains.

In order to ascertain the precise quantity of sugar contained in the above, I subjected 500 grains of the same urine, in a weighed bottle, to fermentation, which showed a loss in car. bonic acid of 10 grains; this multiplied by $2 \frac{1}{4}$, the equivalent for sugar, gives as sugar 45 grains. 45 grains therefore is the whole amount of sugar possible to be obtained, which was further confirmed by the next experiment. 
The fermented liquor, being filtered off from the excess of yeast and evaporated to dryness, afforded $15 \frac{1}{2}$ grains of solid matter, which of course consisted only of urea and salts; this, multiplied by 2 ,

gives the quantity per 1000

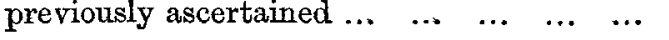

leaves 25 as the saline matter present.

The analysis may therefore now be considered complete, viz. :-

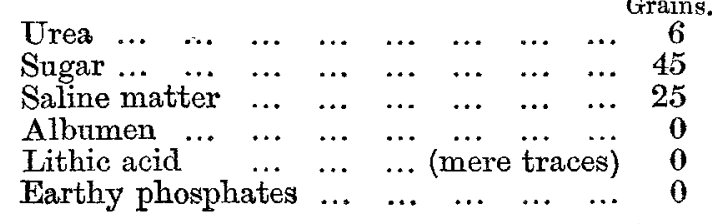

0

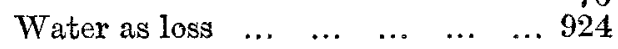

1000

COMPARISONS OF ANALYSES.

Dr. $\mathrm{B}-\mathrm{Mr}$. Horsley. Specific gravity, 1.035.

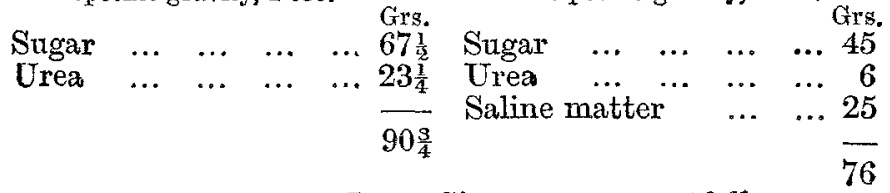

The Laboratory, Cheltenham,

I am, Sir, yours respectfully, June, 1854,

JOHN HORSLEY.

\section{THE MEDICAL PROFESSION AND LIFE ASSURANCE COMPANIES. \\ To the Editor of THE LANCET.}

SIR, - I have forwarded the following note to the Secretary of the Edinburgh Life Office, and, as I told him that I should forward it to THE LANCET for insertion, I shall be obliged by your allowing it to appear in your pages.

I am, Sir, your obedient servant,

Minchinhampton, March, 1854 .

C. H. TURNER.

" Edinburgh Life Assurance Office, London.

"All communications of this nature being intended equally for the benefit and security of the party to be insured, and of the Company, permit me to request the favour of your observing much precision and care in stating the answers, and should the necessary return not be made within seven days from this date, the directors will conclude that you do not consider the life insurable."

Minchinhampton, March, 1854

SrR, - One of your agents has forwarded to me a circular with the above extract, and a request that I would answer a string of medical interrogatories on the life of a person proposing to insure in your office. The same post brought a proposal on another life from the Legal and Commercial Office; that paper I immediately filled up, because mention was made that the proper fees would be paid; your paper I decline to fill up, because you refuse to pay for a communication which you admit is intended "for the benefit and security of the Company." There is no doubt not only that the "security" of your Company, but that of every other, mainly depends on the "precision" of the medical report; you have no right, therefore, to ask such important information gratuitonsly, it is clearly nnjust and in direct variance with the well-admitted maxim, "that the labourer is worthy of his hire." You would not venture to ask a lawyer one point, much less request a string of questions to be replied to, without remuneration; neither would you ask a clergyman to give you a certificate without paying him, and suffer me to assure you that such a state of things will shortly cease with my own profession.

I leave you to draw your own conclusions upon the life which you have forwarded for my consideration now, or at the expiration of "seven" days; in the meantime, however, I shall advise the party to make application to some office whose circumstances will admit of their paying for that upon which the stability of their Company must depend.

I have the honour to be, Sir, your humble servant, C. W. TURNER

To the Secretary of the Edinburgh Life Office, King William-street.

\section{ABUSES AT THE MANCHESTER ROYAL INFIRMARY. \\ To the Editor of The LaxceT.}

SIR,--Devoted as you have erer been to the interests of the medical students, I presume to address you in hopes that (if you will oblige by giving this letter a place in your valuable journal) it may be the means of putting an end to some of the abuses of this hospital. I am one of those fortunate individuals whom the governors of this institution have honoured by accepting the trifling sum of fifty guineas for the inestimable privilege of walking the wards, in company of about ninety equally lucky youths. I have now been a pupil of this hospital two years, and have seen occasionally the gleam of the knife, but I have rarely seen more; for I assure you, Sir, I have never had a fair and distinct view of an operation, on regular operating days, since I have had the happiness to be attached to this establishment. That part of the theatre where the patient is placed is always filled with visitors, surgeons, dressers, and house-surgeons, \&c.; and, although there is ample space for all, they literally club their sagacious heads together, and-but need I say more?- the pupils in the first row endeavour to overtop them, and those in the second and third rows follow their example, and are under the necessity of standing on the rails, posts, \&c., to obtain a casual glance of what is going forward.

Then, the first step towards remedying this evil would be, the enforcing a restriction to prevent the surgeons cramming the operating theatre with individuals who are of no earthly assistance. I appeal to the oldest pupil, to the surgeons themselves, whether I have overstated the plain facts. Let not any one suppose that we (the pupils) object to visitors-far from it; but we must not suffer inconvenience by them, and if they honour us with their presence, they should share our accommodation, and not obstruct our view.

Another cause of complaint is, that the surgeons do not give any clinical instruction at the bed-side. Surely a surgeon, if he wishes to improve his pupils, would make such remarks, as he walked from one bed to another, as are worthy of being communicated; and then, when the pupils leave the hospital, they would have the satisfaction of knowing they have received something for their money.

Trusting, in fairness to the students, that you will insert this communication,

I remain, your obedient and humble servant,

The Library, July, 1854 REFORMER.

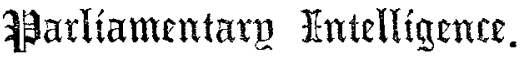

\section{HOUSE OF LORDS-TUESDAY, JULY $11 \mathrm{rH}, 1854$.}

CHARGES AGAINST THE BOARD OF HEALTH.

The Earl of ShafTESBURY said, that he wished to claim the indulgence of their lordships while he called their attention to certain charges which had been made in another place against a public board with which he was connected, and which charges therefore, to some extent, reflected personally on himself. $\mathrm{He}$ had the less inclination to apologize to their lordships for calling their attention to the subject, because the charges to which he referred were of a very serious nature, made in the absence of the parties against whom they were directed, and to whom no notice whatever had been given that such charges would be made. He therefore took the present opportunity of replying to the accusations to which he referred, which he might characterize as unjust and calumnious, and such as he could clearly prove were in every way unfounded. The charges were made by a noble lord in the other house, who had for two or three years been at the head of the department of Woods and Forests, and were directed against the chairman and officers of the Board of Health, the noble lord's former colleagues, against whom he had thought proper to bring forward two or three charges of misconduct so gross and-

Earl FITZWILLIAIr rose to order, and said that the charges which the noble earl was about to cleny did not in any way affect the noble earl as a member of their lordships' house, nor did they arise from anything he had dowe in that house. They were merely charce made in another house against a public board of which the noble earl was a member, and therefore he would submit that this was by no means a case of that nature or personal importance to induce their lordships to depart from their usual mode of proceeding with business, and justify its taking precedence of the order of the day. (Hear, hear.)

The Earl of SHAFTESBCRY had hoped that, after having 